\title{
On Lexical Phonology of Zubairi Arabic
}

\author{
Majid Abdulatif Al-Basri \\ Department of English, Faculty of Arts and Sciences \\ University of Petra, Jordan \\ E-mail: majidabd2@hotmail.com
}

Received: March 20, 2021

Accepted: April 27, 2021

Published: May 9, 2021

doi:10.5296/ijl.v13i3.18628

URL: https://doi.org/10.5296/ijl.v13i3.18628

\begin{abstract}
As its name implies, Lexical Phonology (LP) is a two-sided discipline which is very much pervasive and of a priority for particular interest. It is basically a matter of the systematic correlation of both morphology and phonology as a preliminary to screening endless items and senses. Once postulated and covered with its linguistically theoretical frames, LP has proved attractive, useful and handful in that it turns up so often in such topics as lexical items with their phonological configurations and words with their stratum-based designs. The present paper is a painstaking scrutiny of how LP is thoroughly worked out to demarcate the lexical and phonological boundaries of Zubairi Arabic lexical items with a special reference to the linguistic behavior of affix attachments. It is no doubt a massive task - it is armed with such and such amount of systematization and provided with certain 'harmless looking terms and expressions that are frequently used. In attempt to focus on this point of interaction between phonology and morphology, the paper adopts the line of reasoning that is primarily based on a tabulated description and analysis of examples so as to serve the purposes of setting some comparisons, showing certain contrasts or governing particular rules of applications as far as Zubairi words and expressions are concerned. Among many results the paper has reached is evidently the one that the structure of Zubairi Arabic lexical items is the empirical "container" in which both phonological and morphological lines of representation are sometimes crossed very sharply or sometimes paralleled very endlessly whereby their blurriness may be relative and variable.
\end{abstract}

Keywords: Lexical phonology, Zubairi Arabic, Strata, Lexicon and suffix-attachments

\section{Introduction}

What makes most, if not all, of post-generative theories of phonology somewhat idiosyncratic, rather unique and often remarkable is that they have not undermined the basic principles and 
the real landmarks of Generative Phonology (GP) whose fully authoritative statement was provided by Chomsky and Halle' The Sound Pattern of English (SPE) in 1968. When being initiated from SPE Phonology, Lexical Phonology (LP), among them, attempts to "beautify" the original mother theory's picture and to re-paint it with the same colors but with a different brush by adding, modifying and even deleting some lines of its theoretical arguments. It has been proclaimed that in SPE model of phonology, the morphological dimension is often slipped away from the purely phonological rules when applied to the processes of word-formation, particularly in the realm of affixation. This is generally attributed to state of affairs that morphology has traditionally been cleft between the transformation-generative syntax and the phonological theory. Thus, the domain of morphology has lost its own identity and becomes floating and unfathomable. The model embraced by LP is to go up the curtain for morphological rules to be concatenated together with phonological ones in the majority of lexical items of a particular language or a dialect.

According to some LP scholars, the phonological theory of SPE model is likely to stand as a "requiem mass" for the field of morphology and this metaphorically expresses that attempts are made on SPE theorists' part to restore, albeit survive, morphology, but they are all in vain. Morphology has proved its theoretical stance side by side with phonology to expose many exuberant patterns and underlying representations of lexical items. Being au fait with LP, morphology and phonology have rules to be applied in tandem because of their universal nature and of their outstanding status. LP, in a nutshell, is seen as a two-in-one story in that it refers not only to half of the events but to the whole events that sequentially reconstruct the lexicon of a language via morphological and phonological realities.

On this basis, the present paper is intended to plumb the depths of how Zubairi Arabic (Note 1) lexicon is generally treated on LP grounds, and of what morphological/phonological parameters are worked up to tracing morpheme attachment to certain words. The paper' data sources are the Zubairi lexical items and expressions taken from Al-Hilali's malāmiћ min lahadzāt alxalīots alGarabī lahdzit alzubair (Features of Arab Gulf Dialects: The Dialect of Zubair) (1991) in addition to the researcher' efficiency and reliable intuitions as a native speaker of this dialect (Note 2). What is mostly familiar in phonological studies is that words, lexical items or expressions are phonemically transcribed and then translated in order to enable readers easily read, fully understand and entirely indulge into the paper content.

\section{The Morphology-Phonology Integration}

As stated above, lexicon is that field which seems the very essence of interacting morphological rules with phonological ones. Since lexicon has a very much recognizable status in both derivational and inflectional morphology, it gives way to particular phonological applications (e.g. Tri-syllabic Shorting rule or suffixes conditioned stress shifts) to be operated in the case of attaching certain suffixes to different roots (Kiparsky, 1982a; Mohanan, 1986; Gussmann, 1988).

In its narrow sense, LP is concerned with those lexical items which cannot possibly be derived unless they undergo a number of phonological rules before morphological processes are activated to lead to many alterations affecting their meanings. The lexicon is categorized 
sequentially into strata (levels) whereby each stratum stipulates some sort of amalgamation between morphology and phonology (Booij, 1994). To put it in a practical way, it is of great importance to view that the first stratum (known as the morphological or lexical stratum) includes a group of suffixes added to stems, while the second one (called the phonological stratum) necessitates applying all required phonological rules. In other cases, the two strata likely entail a kind of cyclic-based nature (Note 3) in which phonological rules may either be applied before or after the attachment of suffixes to roots. This option is not always inevitable for all languages or dialects (Mohanan \& Mohanan, 1984). For example, in Zubairi Arabic, the phonological stratum starts manipulating first when a vowel epenthesis of an /-a-/ and /-i-/ sounds is required to separate the suffixes from their stems whose syllables are termed as being heavy and are structured as CVVC or CVCC like (șadr-) ' bosom', (șēd-) (Note 4) 'hunting', ( (āf-) 'see' and (xaðl-) 'let down' in attempt to break consonant clusters. Next, the lexical stratum enters the scene when consonant-initial suffixes such as (-ha) 'her', (-hum) 'their m.', (-na) 'us' and (-kum) 'you m.pl.' are generally attached to these stems as shown in Table 1:

Table 1. Phonological and lexical strata of certain Zubairi lexical items

\begin{tabular}{|c|c|c|c|}
\hline $\begin{array}{l}\text { Input } \\
\text { Stems }\end{array}$ & $\begin{array}{l}\text { Phonological Stratum (1) } \\
\text { Vowel Epenthesis }\end{array}$ & $\begin{array}{l}\text { Lexical Stratum (2) } \\
\text { Suffix Attachments }\end{array}$ & Output Lexical Items \\
\hline șadr- & $-a-$ & -ha & $\begin{array}{l}\text { șadr-a-ha } \\
\text { 'her bosom' }\end{array}$ \\
\hline șēd- & $-i-$ & -hum & $\begin{array}{l}\text { șēd-i-hum } \\
\text { 'their hunting }\end{array}$ \\
\hline Jāf- & $-\mathrm{i}-$ & - na & $\begin{array}{l}\text { Jâf-i-na } \\
\text { 'he saw us' }\end{array}$ \\
\hline xaðl- & $-\mathrm{i}-$ & -kum & $\begin{array}{l}\text { xaðl-i-kum } \\
\text { 'he let you down }\end{array}$ \\
\hline
\end{tabular}

Nevertheless, there is a growing tendency on the part of epenthetic vowels (i. e. /a/ and /i/) to be vetoed in a phonological environment where the consonants become voiceless on either side depending entirely on the rapidity of speech. This, in turn, reshuffles a strata-based scene to be exceptionally one-level ordering (the lexical stratum) instead of two or double-level ordering (the phonological and lexical strata) as seen in Table 2:

Table 2. One-stratum ordered analysis of Zubairi exceptional lexical items

\begin{tabular}{lll}
\hline Input Roots & $\begin{array}{l}\text { Lexical Stratum } \\
\text { Suffix Attachments }\end{array}$ & Output Lexical Items \\
\hline bēt- & -hum & bēt-hum 'their house' \\
\hline limt- & -kum & limt-kum 'I blamed you m. pl.' \\
\hline dirs- & -ha & dirs-ha 'her tooth' \\
\hline
\end{tabular}

In fact, it has been pointed out that LP is sometimes the model whose detailed frames are to carry out the mission of constraining analyses without distorting and marginalizing the basic principles on the one hand and without making a formidable change in major applications on 
the other hand. Accordingly, PL theorists have scarcely ever been hesitant to receive the idea of one-stratum-ordering morphology with welcome when some restrictions are imposed on applying PL rules to some exceptional lexical data (Carr, 1993).

It is worth-stating that the postulation of PL rules and their applications to phonological and lexical strata are not only of a cyclic standard, but they are also manifested as having the nature of non-cyclicality (Halle \& Mohanan, 1985; Booij \& Rubach 1987; McMahon 1990; Borowsky; 1993). That is to say, it is the inflectional suffixes not the derivational ones which are here subsumed under the lexical stratum and which are to be attached to stems before the phonological stratum embodied by any phonological operations is adopted.

In a word, that morphology and phonology are very much interacted in applying rules to lexicon in general heralds the beginning of change that has paved the way for LP to step towards providing "renewed lights" at the end of phonological theory's tunnel.

\section{Method}

By its very nature, LP is set forth to coincide perfectly the phonological context of lexical items with the morphological one. The present paper accordingly adopts a tabulated-based analysis in which tables are widely employed to elucidate very carefully how Zubairi words are subsumed under both phonological and morphological representations in conformity with LP rules, principles and constraints. The tables are not drawn to display results or findings but rather they are used to expose Zubairi word examples: examples which are sometimes cited to reveal some sort of a comparison set between the phonological and morphological applications of rules to Zubiari lexemes. In other cases, the tables illustrate the extent to which affixes (i. e. suffixes) highly affect the morphological picture of some Zubairi words so that a properly phonological frame would be made in harmony.

As has broadly been hinted in the introduction of this paper, the data sources are cited from Al-Hilali (1991). The corpora are various words and expressions spoken by Zubairi people in different daily contexts. Zubairi spoken contexts obviously reflect social, traditional, religious and sometimes humorous situations and occasions in which lexical items are in general used and understood.

\section{Zubairi Stems and Vowel Alternations}

Transparent and intriguing as they are, LP notions are brought about to prove and guarantee that interlocking ties between morphological and phonological processes are highly strengthened to depict and interpret a plenty of phenomena. One of the most dominant phenomena is the one which is known as "derived environment" (Kiparsky, 1982b). Derived environment is really conceived of as being a bilateral phenomenon: it either refers to the context which is occupied by certain types of sounds and which is derived in accordance with suffix attachments or different word forms, or stands for the context in which one/ more sound (s) is/are articulated as a result of a particular phonological rule.

In the first place, Zubairi verbs are of various lexical declensions (Note 5) (the set of various forms) such as Perfective, Imperfective, Transitive, Intransitive and Passive. These verbal 
forms can be differentiated among themselves according to a vowel alteration taking place within their stems. Thus, the general rule of a vocalic alteration here is stated as follows: a high vowel /i/ should be uttered when a verb stem is imperfective transitive. Once the verb becomes imperfective intransitive, the vowel type should be altered into the low vowel /a/ as shown Tables 3 and 4:

Table 3. Verbal stems of imperfective transitive with the incidence of the /i/ Vowel

\begin{tabular}{lll}
\hline The vowel Type & Verbal Stem & $\begin{array}{l}\text { Derived Environment } \\
\text { (Imperfective Transitive) }\end{array}$ \\
\hline la/ & șbir 'to wait & ya-șbir 'he waits' \\
\hline la/ & rbih 'to win' & ta- rbih 'she wins' \\
\hline la/ & Jrig 'to choke' & a-Jrig 'I choke \\
\hline la/ & xrib 'to ruin' & na-xrib 'we ruins' \\
\hline
\end{tabular}

Table 4. Verbal stems of imperfective intransitive with the incidence of the /a/ Vowel

\begin{tabular}{lll}
\hline The vowel Type & Verbal Stem & $\begin{array}{l}\text { Derived Environment } \\
\text { (Imperfective } \\
\text { Intransitive) }\end{array}$ \\
\hline /i/ & wgaf 'to stand up' & yi- wgaf 'he stands up' \\
\hline /i/ & șrax 'to shriek' & ti-șrax 'she shrieks \\
\hline /i/ & țlaৎ 'to go out & i-ṭ laৎ 'Go out' \\
\hline /i/ & frah 'to be happy' & ni-frah 'we are happy' \\
\hline
\end{tabular}

What is overwhelmingly observed in the data of the above tables is that the imperfective markers are also doomed to vowel shifts depending on the transitive/intransitive dichotomy. As such, the imperfective transitive verbs commence with markers like (ya-) 'he', (ta-) 'she' and (na-) 'we', whereas those of imperfective intransitive start with (yi-), (ti-), and (ni-).

Equally important, the concept of derived environment possibly comes into being due to the types of suffixes added to stems rather than due to different declensions as a foregoing statement is made. In Zubairi Arabic, some forms of direct object (DO) pronoun are usually affixed to verbs in a way that it affects the placement of stress on the verbal-stem syllables as a result of their phonological configurations in which the presence or absence of the vowel sound in these pronouns is something conclusive. For instance, the suffixes (-ik) 'you', (-ihum) 'them (m.)', (-ihin) 'them (f.)', (-ini) 'me' and (-aha) 'her' are heard with or without the vocalic elements (i. e. /i/ or /a/) initially. This means that what is in front of us is not a single form of a DO suffix but two forms with two different phonological shapes and that there are two stress patterns occurred in the verbal stems as seen in Table 5:

Table 5. Two different forms of direct object pronoun suffixes with both different phonological shapes and stress patterns

\begin{tabular}{llllll}
\hline Verbal & DO Suffixes & Derived & Verbal & DO Suffixes & Derived \\
Stems & with /i/ or & Environment & Stems & $\begin{array}{l}\text { without } \\
\text { Vowels }\end{array}$ & Environment \\
& $/ \mathrm{a} /$ & & & \\
\hline
\end{tabular}




\begin{tabular}{|c|c|c|c|c|c|}
\hline sa?al- & $-\mathrm{ik}$ & $\begin{array}{l}\text { sal'?al-ik } \\
\text { 'he asked you' }\end{array}$ & sa?al- & $-\mathrm{k}$ & ${ }^{1}$ sa?al-k \\
\hline fahim- & -i-hum & $\begin{array}{l}\text { falhim-i-hum } \\
\text { 'he understood them' }\end{array}$ & fahim- & -hum & ${ }^{1}$ fahim-hum \\
\hline nifad- & -i-hin & $\begin{array}{l}\text { nilfad-i-hin } \\
\text { 'he queried them' }\end{array}$ & nifad- & -hin & ${ }^{1}$ nifad-hin \\
\hline ðibaћ- & $-\mathrm{i}-\mathrm{ni}$ & $\begin{array}{l}\text { ðilbah-i-ni (Note 6) } \\
\text { 'he bothered me' }\end{array}$ & ðibaћ- & $-n i$ & `ðibaћ-ni \\
\hline xațab- & -a-ha & $\begin{array}{l}\text { xatab-a-ha } \\
\text { 'he engaged her to } \\
\text { marry' }\end{array}$ & xațab- & -ha & ${ }^{1}$ xat'ab-ha \\
\hline
\end{tabular}

The other track of creating derived environment is by virtue of applying particular phonological rules to some sort of sounds. Once again, this seems of an urgent requirement for retaining the "co-existence" between morphological and phonological strata on the one side, and for maintaining the cyclic order that harmonizes the two on the other side. The most predominant phonological rule that has intrigued LP scholars is Re-syllabification Rule (Levin 1985; Harris 1994; Giegerich, 1999). In its "Old Testament" version, Re-syllabification Rule was appealed to pinpoint how allophones of English plosives can be re-syllabified in the light of shifting stress placement in some lexical items (Myers, 1987; Borowsky, 1990). However, it is possible to admit that the "New Testament" copy of Re-syllabification Rule has a lot amended the original lines of the argument whereby references have been made, for example, as to how syllabic onsets and codas are subject to phenomena like extra-syllabicity and ambi-syllabicity (Note 7).

In Zubairi Arabic, Re-syllabification Rule blends in homogeneously with the behavior of a group of sounds known as guttural consonants (Ladefoged \& Maddieson, 1996). The very manipulation of the term 'guttural' is undoubtedly self-contained and exclusive in that it is not a label referring to a sound place of articulation nor is it used for segmental manner of articulation. It is, however, a sound quality whose phonetic "atmosphere" is the throat or glottis and all gutturals are throaty-based consonants: / $\mathrm{x}$ and $\mathrm{\gamma} /$ are velar fricatives, $/ \mathrm{h}$ and $\mathrm{S} /$ are pharyngeal fricatives and $/ \mathrm{h} /$ is a glottal fricative.

Guttural Re-syllabification Rule is now introduced to account for a close relation drawn between two types of short vowels and the mapping of a syllable structure. One of the commonest properties of Zubairi syllable templates is that high vowels like / $\mathrm{i}$ and $\mathrm{u} / \mathrm{are}$ usually the peaks of non-final light syllables, whereas a low vowel /a/ is the peak of heavy syllables as shown in Table 6:

Table 6. The distribution of high vowels /i and $\mathrm{u} /$ and a low vowel /a/ in different syllable templates

\begin{tabular}{llllll}
\hline $\begin{array}{l}\text { High } \\
\text { Vowel }\end{array}$ & $\begin{array}{l}\text { Light } \\
\text { Syllable }\end{array}$ & Examples & $\begin{array}{l}\text { Low } \\
\text { Vowel }\end{array}$ & $\begin{array}{l}\text { Heavy } \\
\text { Syllable }\end{array}$ & Examples \\
\hline li/ & CV & șigaS & la/ & CVC & galab \\
& & 'he hit (someone/something)' & & & 'he overturned' \\
\hline
\end{tabular}




\begin{tabular}{llllll}
\hline /u/ & $\mathrm{CV}$ & $\begin{array}{l}\text { kubir } \\
\text { 'he was young' }\end{array}$ & /a/ & CVC & $\begin{array}{l}\text { zahig } \\
\text { 'he was bored' }\end{array}$ \\
\hline /i/ & $\mathrm{CV}$ & $\begin{array}{l}\text { misah } \\
\text { 'he erased (something)' }\end{array}$ & /a/ & CVC & $\begin{array}{l}\text { țarid } \\
\text { 'he expelled (someone)' }\end{array}$ \\
\hline
\end{tabular}

Applying Guttural Re-syllabification Rule opens many avenues for guttural consonants to constraint, albeit change, the above-mentioned traits of some syllable structures of Zubairi lexical items. Guttural consonants exercise their considerably phonetic influence on the type of a vowel following them in non-final light syllables. Thus, they require a low vowel /a/ to replace high vowels /i/ and / $\mathrm{u} /$ leading to a new derived environment as seen in Table 7:

Table 7. A comparison between non-guttural original environment and guttural derived environment

\begin{tabular}{|c|c|}
\hline Non-Guttural Original Environment & Guttural Derived Environment \\
\hline kitab/ya-kitib 'he wrote/writes' & $\begin{array}{l}\text { halam/y-halim } \\
\text { dreamed/dreams' }\end{array}$ \\
\hline gumaz/ya-gumaz 'he jumped/jumps' & xalat/y-axalit 'he mixed/mixes' \\
\hline $\begin{array}{l}\text { nifab/ya-nifab 'he stuck/sticks in someone's } \\
\text { craw' }\end{array}$ & yaraf/y-yarif 'he ladled/ladles' \\
\hline rigid/ya-rigid 'he lain down/lies down' & Sabar/y-Yabir 'he passed/passes' \\
\hline
\end{tabular}

To recapitulate, vowel shifts are totally viewed as "the flesh and blood" of Zubairi Arabic word stems. The morphological "texture" of these stems owes nothing to Zubairi lexicon without maintaining certain phonological vocalic alternations occurred in word positions. Moreover, vowel alterations, once coinciding perfectly with the internal structure of word stems, are chiefly based on the factor of what is usually called a vowel "height": high/low vowels in question.

\section{Lexical and Phonological Orientations of Zubairi Strong/Weak Verbs}

Of all verbal classifications, whether being from syntactic or semantic perspectives, strong/weak classes of verbs remain extremely debatable and enigmatic simply because their morphological and ultimately phonological lines are not fully intersected in that it seems difficult to make a principled separation between them. However, their suffix attachments to stems divulge a considerable variation in terms of the rules operated and the principles formulated. Strong and weak verbs have received an in-depth treatment among scholars of historical linguistics, morphology and syntax to depict their pattern of conjugation (Veith, 1984; Quirk et al, 1985).

In Zubairi Arabic, strong/weak verbal distinction is entirely reckoned as "a mirror image" that portrays the morpho-phonological identity of consonantal stems. What lexically characterizes Zubairi weak verbal forms is that their stems are governed by the following two criteria: the first one is that they should involve certain consonantal segments like /w/, /y/ and/?/, and the second one is that the three consonants are realized phonologically as the $/ \overline{\mathrm{a}} /$ vowel in particular declensions both word-initially and word medially as illustrated in Table 8: 


\section{MInstitute Macrothink $_{\text {Int }}$}

International Journal of Linguistics

ISSN 1948-5425

2021, Vol. 13, No. 3

Table 8. Zubairi weak verbal roots with the $/ \bar{a} /$ realization in particular declensions word-initially and word-medially

\begin{tabular}{|c|c|c|}
\hline $\begin{array}{ll}\text { Weak } & \text { Verbal } \\
\text { stems } & \end{array}$ & Position of the /ā/ Realization & Declensional Examples \\
\hline wifam 'to tattoo' & the $/ \overline{\mathbf{a}} /$ vowel initially & $\begin{array}{l}\text { yā-fim 'he tattooed } \\
\text { tā-Sim 'she tattooed' }\end{array}$ \\
\hline Pamin 'to believe' & the $/ \bar{a} /$ vowel initially & $\begin{array}{l}\text { yā-min 'he believes' } \\
\text { tā-:min 'she believes' }\end{array}$ \\
\hline Jayl 'to carry' & the $/ \bar{a} /$ vowel medially & $\begin{array}{l}\text { Jāl 'he carried (something)' } \\
\text { Jāl-at 'she carried' }\end{array}$ \\
\hline mayl 'to incline' & the $/ \bar{a} /$ vowel medially & $\begin{array}{l}\text { māl 'he inclined' } \\
\text { māl-at 'she inclined' }\end{array}$ \\
\hline
\end{tabular}

On a different footing, Zubairi strong verbs do not undergo the realm of a vocalic realization, but they are instead subsumed under the phonological context of consonantal exponents. That is to say, the consonantal segments which lexically form strong verbal roots should be at the core of building up the stems as well as their declensions, and hence there is no way to replace any of these consonantal sounds by either vowel or zero realization as shown in Table 9:

Table 9. Zubairi strong verbs of particular declensions with consonantal exponents in their roots and stems

\begin{tabular}{|c|c|c|}
\hline Roots & Stems & Declensional Examples \\
\hline xlṣ & xaliṣ 'to finish' & $\begin{array}{l}\text { ya-xaliṣ 'he finishes } \\
\text { ya-xlṣ-un 'they finish' }\end{array}$ \\
\hline ḍk & dahik 'to laugh' & $\begin{array}{l}\text { ya-ḍahik 'he laughs' } \\
\text { ta-ḍhik 'she laughs' }\end{array}$ \\
\hline lihg & lahig 'to follow' & 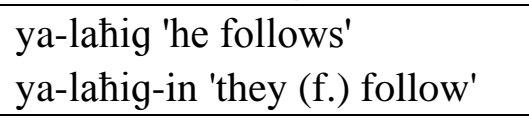 \\
\hline $\mathrm{yms}$ & yamis 'to dip' & $\begin{array}{l}\text { ya-yamis 'he dips (something)' } \\
\text { a-yamis 'I dip (something)' }\end{array}$ \\
\hline
\end{tabular}

On account of their frequently concomitant occurrence in Zubairi Arabic lexical items in general and in verbal forms in particular, the lexical and phonological axes are still shaded into each other in dealing with miscellaneous rules applicable to some suffixes whose attachment to certain verbs unveils modifications. For instance, derivational suffixes like (-an-) and (-in-) entail applying Geminate Rule to their $/ \mathrm{n} /$ consonant whenever they are followed by a feminine inflectional object suffix (-ih). However, verbs with de-geminating /n/ are odd and are scarcely heard by Zubairi speakers and thus they are highly questionable (Note 8). This is lucidly indicated in Tables 10 and 11: 
Table 10. The (-an-) derivational suffix as de-geminated and geminated before the (-ih) inflectional suffix

\begin{tabular}{ll}
\hline $\begin{array}{l}\text { The (-an-) Derivational Suffix before } \\
\text { Applying Geminate Rule }\end{array}$ & $\begin{array}{l}\text { The (-an-) Derivational Suffix after } \\
\text { Applying Geminate Rule }\end{array}$ \\
\hline lhag-an-ih 'they (f.) followed him' & lhag-ann-ih 'they (f.) followed him' \\
\hline ðkir-an-ih 'they(f.) remembered him or it' & ðkir-ann-ih 'they (f.) remembered him or it' \\
\hline ydaS-an-ih 'they (f.) let it' & ydaS-ann-ih 'they (f.) let it' \\
\hline gdab-an-ih 'they (f.) caught it' & gḍab-ann-ih 'they (f.) caught it' \\
\hline
\end{tabular}

Table 11. The (-in-) derivational suffix as de-geminated and geminated before the (-ih) inflectional suffix

\begin{tabular}{ll}
\hline $\begin{array}{l}\text { The (-in-) Derivational Suffix before } \\
\text { Applying Geminate Rule }\end{array}$ & $\begin{array}{l}\text { The (-in-)Derivational Suffix after } \\
\text { Applying Geminate Rule }\end{array}$ \\
\hline ya-ḍrib-in-ih 'they (f.) hit him' & ya-ḍrib-inn-ih 'they (f.) hit him' \\
\hline ya-șil-in-ih 'they (f.) visit him' & ya-șil-inn-ih 'they (f.) visit him' \\
\hline ya-ḑmaS-in-ih 'they (f.) collect something' & ya-ḑmaS-inn-ih 'they (f.) collect something' \\
\hline ya-kfax-in-ih 'they (f.) crash it' & ya-kfax-inn-ih 'they (f.) crash it' \\
\hline
\end{tabular}

Central to the foregoing miscellaneous rules that have twined the morphological perspective with phonological one of Zubairi strong verbs is the matter of vowel lengthening (more adequately vowel duration). Once again, when added to different verbal declensions, there is an exponential increase on the part of a set of derivational suffixes ( most of them are vowel sounds by themselves) to behave phonologically in a diverse way from what is supposed to be usual: the vowel element of such suffixes as (-i-), (-u-), (-o-), (-ti-), (-tu-) and (-na-) is totally under the influence of Lengthening Rule as far as they are followed by the inflectional suffix (-h). The oddity and unfamiliarity may arise if the vocal segment of the suffixes in question is not lengthened and this, in turn, may give rise to a type of pronunciation with which Zubairi people are not accustomed. Table (12) illustrates the word examples whose derivational-suffix vowels are short and then lengthened:

Table 12. Derivational-suffix vowels before and after applying lengthening rule

\begin{tabular}{|c|c|}
\hline $\begin{array}{l}\text { Words with Derivational-Suffix } \\
\text { Vowels Before Lengthening }\end{array}$ & $\begin{array}{l}\text { Words with Derivational-Suffix } \\
\text { Vowels After Lengthening }\end{array}$ \\
\hline iriћm-i-h 'Show (f.) mercy to him/it' & iriћm-ī-h 'Show (f.) mercy to him/it' \\
\hline ismaG-u-h 'Listen (m. pl.) to him' & ismaY-ū-h 'Listen (m. pl.) to him' \\
\hline țag-o-h 'they hit him' & țag-ō-h 'they hit him' \\
\hline Sazam-ti-h 'you (f.) invited him' & Sazam-tī-h 'you (f.) invited him' \\
\hline xarraS-tu-h 'you (m. pl.) scared him' & xarraS-tū-h 'you (m. pl.) scared him' \\
\hline țubax-na-h 'we cooked it' & țubax-nā-h 'we cooked it' \\
\hline
\end{tabular}

All in all, whether a lexical item is a strong verb or a weak one leaves much to admit that both morphological and phonological manifestations contribute more to the etymology of Zubairi lexicon which is mostly descended from Najdi Arabic (Note 9). 


\section{The Morphology and Phonology of Zubairi Plural Forms}

Like other Arabic dialects and sub-dialects (Anis, 1973; Al-Jundi, 1975), Zubairi Arabic exhibits the nominal plurality when singular forms are considerably augmented via three common processes, two of which are gender-based formations and the other one is neutrally oriented. Morphologically speaking, the first plural process comes into being owning to the attachment of the masculine suffix (-īn) to nouns, whereas the second plural process is chiefly attributed the addition of the feminine suffix (āt) to nominal forms. What discriminates the third plural formation from the first two sorts is that it does not fall within the ambit of the regularity, familiarity and grammaticality of particular suffix-attachment parameters: it does not stick as closely as possible to the atmosphere of a rule-governed framework from which plurality is emanated. Accordingly, it is not surprised that this type of plural form is usually termed as the "broken plural". Table (13) gives a panoramic look at the three Zubairi types of plural:

Table 13. Zubairi three plural processes of nominal formations

\begin{tabular}{|c|c|c|c|c|c|}
\hline \multirow{2}{*}{$\begin{array}{l}\text { Masculine } \\
\text { Singular } \\
\text { Forms }\end{array}$} & $\begin{array}{l}\text { Masculine } \\
\text { Plurals with }\end{array}$ & \multirow{2}{*}{$\begin{array}{l}\text { Feminine } \\
\text { Singular } \\
\text { Forms }\end{array}$} & $\begin{array}{l}\text { Feminine } \\
\text { Plurals with }\end{array}$ & \multirow{2}{*}{$\begin{array}{l}\text { Masculine } \\
\text { and Feminine } \\
\text { Singular } \\
\text { Forms }\end{array}$} & \multirow[t]{2}{*}{$\begin{array}{r}\text { Broken } \\
\text { Plurals }\end{array}$} \\
\hline & $\begin{array}{l}\text { the (-īn) } \\
\text { Suffix }\end{array}$ & & $\begin{array}{l}\text { the (-at) } \\
\text { Suffix }\end{array}$ & & \\
\hline maynūn & miyan-ī:n & mxarfah & mxraf-āt & be:t & byu:t \\
\hline 'mad' & 'mad men' & 'a senile' & 'senile women' & 'a house' & 'houses \\
\hline malৎūn & malG-1̄:n & mahafah & mahaf-āt & taksi & taka:si \\
\hline 'cursed' & 'cursed men' & 'a hand fan' & 'hand fans' & 'taxi' & 'taxies' \\
\hline mșayif & mșayif-ī:n & bațanyah & bațany-āt & țasah & ț̣̂s \\
\hline 'tardy' & 'tardy men' & 'a blanket' & 'blankets' & 'a bowl' & 'bowls' \\
\hline
\end{tabular}

From a phonological point of view, nominal plural suffixes are, to great extent, subject to the following relative operations: vowel lengthening, vowel epenthesis and vowel/consonant substitution. For example, as elucidated above, the feminine plural suffix (-ât) fulfills the purpose of replacing the feminine singular suffix (-ah) on a lexical ground. Nevertheless, the phenomenon of substitution is also to exceed the lexical limits of such suffixes to cover their own phonological parameters. The phonological format of the feminine singular suffix (-ah) is therefore extremely shifted by introducing the plural one (-ât) whereby the /a/ vowel and the $/ \mathrm{h} /$ consonant of (-ah) undergo applying two rules: the former is lengthened to be $/ \bar{a} /$, whereas the latter is replaced by / $t /$. In other contexts, the rule of a vowel epenthesis is very much exploited particularly in conformity of some of the broken plural forms. It seems usual, albeit natural, for some Zubairi singular nouns to change into broken plural forms when the/ i/ vowel is added word-finally as if it played the role of the plural 'maker'. This is illustrated in Table 14: 
Table 14. Broken plural nouns with the /i/ vowel addition word-finally

\begin{tabular}{ll}
\hline Singular Nouns & Broken Plural Nouns \\
\hline Makwa (Note 10) 'a buttock' & mukawi 'buttocks' \\
\hline șīniya 'a plate' & șuwani 'plates' \\
\hline tritfiya 'an earring' & taratfi 'earrings' \\
\hline turbaya (Note 11) 'a bed' & tarabi 'beds' \\
\hline
\end{tabular}

As earlier stated in this section, the broke plural has marked an important milestone, if not a turning point, in zubairi nominal plurality. Unlike other types of plural patterns, it is frequently accompanied with a variety of divergent singular forms, and is phonologically mapped with different syllabic templates as seen in Table 15:

Table 15. Zubairi broken plural nouns with different syllabic templates

\begin{tabular}{lll}
\hline Divergent Singular Nouns & Broken Plural Nouns & Different Syllabic Templates \\
\hline kitāb 'a book' & kutub 'books' & CVCVC \\
\hline Srubi 'a nomad' & Surban 'nomads' & CVCCVC \\
\hline rayāl 'a man' & riyāyīl 'men' & CVCVCVC \\
\hline șūrah 'a picture' & șwar 'pictures' & CCVC \\
\hline
\end{tabular}

In short, Zubairi plural nouns are seemingly of peculiar nature simply because they are partially detached from the plural system of Standard Arabic, and they are, in a way or another, designed to make so direct an impact on setting up the overall of Zubairi linguistic system.

\section{Conclusion}

Though tackled eclectically more than comprehensively, the upshot of the above discussion unveils that LP apparently posits various Zubairi dialect-specific operations, concepts and notions in order to elucidate the extent to which morphological and phonological rules and parameters are tightly amalgamated. This "binary" amalgam is the product of asserting that Zubairi morphology and phonology are reliable scales not complete dichotomies used to account for various processes and phenomena taken place in the case of lexical items. The emergence of strata-based approach is conceived of as solid evidence of how different lexical formations of Zubairi Arabic (definitely including other dialects) are built up symmetrically.

Fascinating as it is, Zubairi LP is considered a "stepping stone" towards studying the morpho-phonological treatment of suffix attachments of distinct types and of contrastive patterns. Adopting a particular kind of suffixes has a knock-on effect over the output of the phonological configuration of a lexical item: the more suffixes are added differently to words, the more phonological shapes of words are obtained. This, as a matter of fact, leans towards the view that languages and dialects of innumerable affixation processes are "fertile soil" for phonological rules to apply and then to produce ever-lasting sets of lexemes. It becomes rather apparent that phonology is considered intrinsically a linguistic "container" within which the morphology of Zubairi words finds its own identity and infinity. In brief, a suffix attachment is not a merely lexical process but rather it is also a fully phonological mission. 


\section{References}

Al-Hilali, K. T. (1991). Features of Arab gulf dialects: the dialect of zubair. The Arab Gulf, 3(1-2), 155-183.

Al-Jundi, A. A. (1978). Arabic Dialects in the Heritage. Libya:Paddaaril Sarabijja lil kitaab.

Anis, I. (1973). On Arabic Dialects. Cairo: maktabatul Panylolmisrijja.

Booij, G. (1994). Lexical phonology: a review. Lingua, 4, 225-255.

Booij, G., \& Rubach, J. (1987). Postcyclic vs. postlexical rules in lexical phonology. Linguistic Inquiry, 18, 1-44.

Borowsky, T. (1990). Topics in the lexical phonology of English. New York: Garland.

Borowsky, T. (1993). On the word level. In S. Hargus, \& E. M. Kaisse (Eds.), Studies in Lexical Phonology, Phonetics and Phonology (pp.199-234). San Diego: Academic Press. https://doi.org/10.1016/B978-0-12-325071-1.50013-3

Carr, P. (1993). Phonology. London: Macmillan. https://doi.org/10.1007/978-1-349-22849-2

Chomsky, N., \& Halle, M. (1968). The sound pattern of English. New York: Harper \& Row.

Giegerich, H. J. (1999). Lexical strata in English: morphological causes. Phonological Effects. Cambridge: CUP. https://doi.org/10.1017/CBO9780511486470

Gussmann, E. (1988). Review of Mohanan (1986). Journal of Linguistics, 24, 232-239. https://doi.org/10.1017/S0022226700011683

Morris, H., \& Mohanan, K. P. (1985). Segmental phonology of Modern English. Linguistic Inquiry, 16, 57-116.

Harris, J. (1994). English sound structure. Oxford: Basil Blackwell.

Kiparsky, P. (1982a). Lexical phonology and morphology. In I. S. Yang (Ed.), Linguistics in the morning calm (pp. 3-91).Hanshin: Seoul.

Kiparsky, P. (1982b). From cyclic phonology to lexical phonology. In H. Van der Hulst, \& N. Smith (Eds.), The Structure of Phonological Representations, Part I (pp. 131-175). Dordrecht: Foris.

Johnstone, T. M. J. (1967). Eastern Arabian dialect studies. Oxford: Oxford University Press.

Ladefoged, P., \& Maddieson, I. (1996). The sounds of the World's Languages. Oxford: Blackwell.

McMahon, A. M. S. (1990). Vowel shift, free rides and strict cyclicity. Lingua, 80, 197-225. https://doi.org/10.1016/0024-3841(90)90020-L

Mohanan, K. P. (1986). The theory of lexical phonology. Dordrecht: D. Reidel. https://doi.org/10.1007/978-94-009-3719-2 


\section{Macrothink}

International Journal of Linguistics

ISSN 1948-5425

2021, Vol. 13, No. 3

Mohanan, K. P., \& Mohanan, T. (1984). Lexical phonology and the consonant system in Malayalam. Linguistic Inquiry, 15, 575-602.

Myers, S. (1987). Vowel shortening in English. Natural Language and Linguistic Theory, 5, 485-534. https://doi.org/10.1007/BF00138987

Quirk, R., Greenbaum, S., Leech, G., \& Vartivik, J. (1985). A comprehensive grammar of contemporary English. London: Longman.

Veith, W. H. (1984). The strong verb conjugation in modern English compared with modern German. $L B, 73,39-57$.

\section{Notes}

Note 1. From a dialectological angle, Zubairi Arabic reveals some sort of affinity to Arab Gulf dialects rather than to Iraqi Arabic though the town of Zubair lies in South of Iraq and part of Basrah Governorate.

Note 2. Zubair is the researcher's home town where he was born and grew up.

Note 3. Cyclic and non-cyclic accounts of strata are something appealing, albeit prevailing, particularly when they are treated differently according to which version of LP models is intentionally involved. Here, we are in front of two copies: the model of lexical phonology (the one on which this paper pivots) and that of post-lexical phonology. The latter embarks upon attaching only inflectional suffixes to words in order to proscribe their own cyclicality with phonological operations.

Note 4. Of all vowel segments of Zubairi Arabic (perhaps other Iraqi and Arab Gulf varieties), the $/ \overline{\mathrm{e}} /$ vowel remains a special case for the simple reason that its pronunciation is the product of a "phonetic-based distortion" of the Standard Arabic counterpart /ay/ as shown in (i) and (ii):

(i) bēt 'a house', lēt 'I hope', șēd 'hunting' and so forth.

(ii) bayt 'a house, layt 'I hope', șayd 'hunting' and so forth.

Note 5. Notably marked as serving syntactic/semantic functions, Standard Arabic verbal forms (including definitely those of its sub-dialects) show distinctive declensions whose typological categorization relies not only on a tense factor but also on other factors like number, gender and person and accordingly suffix attachments are subject to them.

Note 6. This word is used here in its connotative sense instead of its denotative one since its denotation means "to slaughter or to kill".

Note 7. These are the most salient phenomena coped with different templates of a syllable. They are, phonologically speaking, thought of as exceptions rather than as rules of mapping certain word syllables. 


\section{Macrothink}

International Journal of Linguistics

ISSN 1948-5425

2021, Vol. 13, No. 3

Note 8. Despite their own oddity, de-geminate verbs do not semantically contrast with their own geminate cognates because in either case, verb meanings remains constant, and this evinces that Zubair people understand both of them.

Note 9. Roughly speaking, the term "Najdi Arabic" refers to a variety that spoken by those who are inhabitant in the eastern part of Arab Peninsula, i. e. Saudi Arabia. For a fuller account on this variety, see Johnstone (1967).

Note 10. Though referring to a taboo meaning in particular contexts, this word is cited here to stand for part of a human body.

Note 11. This is a loan word which is originally borrowed from Persia. Zubairi Arabic, among many, is a dialect whose lexicon is full of loan words of different languages, especially Persian and Turkish.

\section{Copyrights}

Copyright for this article is retained by the author(s), with first publication rights granted to the journal.

This is an open-access article distributed under the terms and conditions of the Creative Commons Attribution license (http://creativecommons.org/licenses/by/4.0/) 